study of sucrose, starting with the sodium sucrates and their condensates with chloro compounds; and a corrosion project including an investigation of the effect of the structure of organic additives, with particular emphasis on physical and chemical inhibition mechanisms around the neutrality point. Five papers published during the year are listed, as well as the titles of six others submitted for publication.

\section{Climatic Tables}

ThE Meteorological Office receives a very large number of inquiries for climatic data for places in all parts of the world from industrial firms and others. Many of these inquiries relate to temperature, humidity and precipitation and it has been the practice to prepare and sell mimeographed tables of these elements to inquirers. The data most required are now being published (Air Ministry: Meteorological Office. Tables of Temperature, Relative Humidity and Precipitation for the World. London : H.M. Stationery Office, 1958) in six parts as follows : (1) North America, Greenland and the North Pacific Ocean; (2) Central and South America, the West Indies and Bermuda (to be published shortly); (3) Europe and the Atlantic Ocean north of $35^{\circ} \mathrm{N}$. (to be published shortly); (4) Africa, the Atlantic Ocean south of $35^{\circ} \mathrm{N}$., and the Indian Ocean (5) Asia; (6) Australia and the South Pacific, Antarctica. Each part gives monthly values of the following information for a carefully selected and representative set of several hundred observing stations : temperature: average daily maximum and minimum, average highest and average lowest in each month, absolute maxima and minima; relative humidity : average values, varying times but selected as far as possible to give night and midday values; precipitation: average monthly fall, maximum in $24 \mathrm{hr}$., average number of days of $0.01 \mathrm{in}$. or more. Each part has a map showing the stations, an index, and bibliography of sources, and the latitude, longitude and height of each station is given in the tables. Great care has been taken in collaboration with the British Government's Permanent Committee on Geographical Names to give place-names under all the forms by which each is likely to be known, a matter of no small difficulty for places in the Far East and U.S.S.R. All six volumes are also being made available bound into one book.

\section{The Absorption Spectrum of Water Vapour}

IN his paper, "Das Spektrum des Wasserdampfes" (Ber. Deutsch. Wetterdienstes, Nr. 44, 6 ; 1958), W. Regula gives a valuable summary of the theory of, and experimental information on, the absorption spectrum of water vapour over the wave-length range $1.35 \mathrm{~cm}$. to $300 \mathrm{~A}$. The positions of the absorption bands are given in tables under the type of process responsible. The intensities are indicated qualitatively (strong, medium, weak) in most instances. The paper may be useful to physicists as well as meteorologists.

\section{Spectrum of the Night Sky}

IN a paper on the altitude of atmospheric layers emitting the lines [O I] $5577 \mathrm{~A} .$, [O I] $6300 \mathrm{~A}$. and [Na I] $5892 \mathrm{~A}$. (Pub. de l'Observ. de Haute-Provence, 3 , No. 36 ; 1957), Jean Dufay and Tcheng Mao-Lin have re-examined all the observations of the bright lines in the night-sky spectrum. Following the method described by Barbier, correetions for extine- tion and for scattered light have been made. Taking into account only the molecular scattering and the absorption by atmospheric ozone, the following equivalent heights are obtained: $\lambda, 5577 \mathrm{~A} ., z$, $195 \mathrm{~km}$. ; $\lambda, 5892 \mathrm{~A} ., \quad z, 200$ (or 230 ) km. ; $\lambda, 6300 \mathrm{~A}$., $z, 280 \mathrm{~km}$. If, however, a thin layer of haze is present in the lower atmosphere, producing at the zenith the additional optical density $D_{0}(v)=0.0050$, these heights may be reduced to 170,170 (or 200) and $250 \mathrm{~km}$., respectively. The uncertainty arising from a selective absorption by water vapour and by oxygen molecules, chiefly from the emission of the OH.band, is also discussed.

\section{Cricket Bat Willow}

Salix alba var. caerulea is as a timber tree unique in Britain, in that the care lavished on it during (and after) its lifetime is reminiscent more of the practices of horticulture than of forestry. This is the result of the high value of its timber when well grown. Current methods of producing timber of the best quality are fully described in "Cultivation of the Cricket Bat Willow" (Forestry Commission. Bulletin No. 17. Pp. vi $+34+33$ plates. London: H.M. Stationery Office, 1958. 5s. net). Rooted or unrooted 'sets' (cuttings) are planted widely (at least $30 \mathrm{ft}$. apart), lateral branches are removed early and buds appearing on the main stem are rubbed out before they become woody, to a height of $8 \mathrm{ft}$. Thus a mature stem $8 \mathrm{ft}$. long and free of knots is produced, but even so, only the lower part of the trunk may give timber suitable for cricket bats of the highest quality. Rapid growth gives the desired sapwood (heart wood is not used in bat making) with annual rings up to 1 in. in width, and this with a straight grain combined with toughness and ability to withstand compression are all characters looked for in the timber by the bat maker. It is now known that male as well as female trees may combine all these desirable qualities in their wood, but they will be lacking unless the site is carefully chosen, insect pests controlled, and protection from grazing animals afforded, and even then 'stain' may develop in the timber, or water-mark disease (due to Bacterium salicis Day) affect the trees, rendering them virtually useless.

\section{Control of Aquatic Weeds}

Progress in the control of weeds on agricultural land has not been paralleled by the evolution of reliable methods for the control of aquatic weeds. Present-day practices and the results of recent research in this field are summarized by Aylwin $P$. Chancellor in "The Control of Aquatic Weeds and Algae" (pp. 20. London : H.M. Stationery Office, 1958. 2s. 6d. net). Mechanical methods of removing weeds from ponds and lakes are often preferable to chemical means, but for emergent weeds in still or running water the use of growth substances (particularly sodium $2: 2$-dichloropropionate) offers great promise. Sodium arsenite can be used to control submerged weeds in still water and is effective at concentrations that are harmless to fish. Submerged weeds in running water cannot be satisfactorily controlled, while chlorine and copper sulphate, both effective in controlling algae, have the disadvantage of extremely high toxicity to fish. Added to this is the fact that if a heavy growth of algae is killed off, the products of decay and the great reduction in the oxygen content of the water may be undesirable. Treatment in spring or early summer may kill the 